\title{
SCIENCE COMPETENCY OF ARGENTINIAN UNIVERSITY STUDENTS IN THE FIRST YEAR OF BIOCHEMISTRY AND BIOTECHNOLOGY COURSES
}

\author{
Claudia Beatriz Falicoff \\ National University of the Littoral, Argentina \\ E-mail: falicoff@fbcb.unl.edu.ar \\ Jose Manuel Domínguez Castiñeiras \\ University of Santiago de Compostela, Spain \\ E-mail: josemanuel.dominguez@usc.es \\ Hector Santiago Odetti \\ National University of the Littoral, Argentina \\ E-mail: hodetti@fbcb.unl.edu.ar
}

\begin{abstract}
The aim of this study is to assess the science competency of university students enrolling in the School of Biochemistry and Biological Sciences (first year of the courses of Biochemistry and Biotechnology at the Universidad Nacional del Litoral de Santa Fe, Argentina) and examine the effects of these courses on their competencies of Chemistry proficiency. The concept of science competency has been drawn from the 2006 Program for International Student Assessment (PISA). To collect the information, two ad hoc questionnaires were drafted with questions addressing three science sub-competencies: identifying scientific issues (ISI), explaining phenomena scientifically (EPS) and using scientific evidence (USE). The first questionnaire was designed with the aim to inquire into the initial sub-competencies of the first-year students $(n=84)$. The second one $(n=50)$ was designed to explore the influence of the courses on their developments of such sub-competencies.

The results indicate that first-year students started with a low performancelevel for all the sub-competencies assessed but the first-year of education influenced to develop the sub-competencies identifying scientific issues and explaining phenomena scientifically. Performance levels on using scientific evidence decreased. Therefore, the findings suggested that the courses in the first year need to help students or boost this subcompetency to be able to draw conclusions based on evidence about science-related issues.
\end{abstract}

Key words: chemistry, higher education, science competency.

\section{Introduction}

The citizens of the 21 st century must analyze situations and make decisions on issues that have to do with either scientific knowledge or technical skills. The teaching of science should not be just concerned with the transmission of a series of unconnected, often obsolete items of knowledge; nor should the role of student bodies be to merely accrue such knowledge. On the contrary, a new perspective implies promoting a teaching model that helps students to develop more consistent, flexible and especially critical comprehension (Hodson, 2003). 
Claudia Beatriz FALICOFF, Jose Manuel Domínguez CASTIÑEIRAS, Hector Santiago ODETTI. Science Competency of Argentinian University Students in the First Year of Biochemistry and Biotechnology Courses

PROBLEMS

OF EDUCATION

IN THE $21^{\text {st }}$ CENTURY

Volume 62, 2014

For this reason, the teaching of science must incorporate a focus based both on students' day-to-day experiences as well as on the ways in which scientific knowledge may meet the needs of society today. That is, the use of "context" as the basis to design the curricula and teaching in the classroom (Gilbert, 2006; Ultay \& Calik, 2012).

As the Nuffield Report (Osborne \& Dillon, 2008) underlines, traditional science education is contented with transmitting a vision of science that is insufficient to meet the needs of youths, and incapable of preparing them to understand the role of science and technology in today's world. The greatest concerns of humankind nowadays are food, health, energy, water, climate change; and it is clear that such problems will not be addressed nor solved without important scientific contributions, nor without citizens understanding them and becoming engaged (Calik \& Coll, 2012; Calik, Turan \& Coll, 2013).

The PISA 2006 (OECD, 2006) focused its attention on Science competency. "In the definition proposed here, science competency is conceived as a continuum encompassing from the lowest to the most advanced levels of science competency" (OECD, 2006, p. 26). In other words, it is considered that individuals possess several degrees of science competency and not that they may or not possess it in absolute terms (Bybee, 1997). The PISA statements evidence a turnaround in the approach to teaching that involves all stages of education, not only the basic ones but the renovation of university education. The need is underlined to focus more on how and what the knowledge is used for. That is, the ability to solve problems is valued more than memorized knowledge (Bybee, 1997; Harlen, 2002). The concept of science competency from PISA 2006 includes three science sub-competencies: identifying scientific issues (ISI), explaining phenomena scientifically (EPS) and using scientific evidence (USE).

Argentina, as a member country, has taken part together with other 56 countries from all over the world in the PISA 2006 study. The results achieved by Argentinian teenagers (aged 15 years) were alarming, as for science competency they ranked $51^{\text {st }}(\mathrm{OECD}, 2008)$. In the studies of 2009 and 2012, the evolutions were negative as they achieved position no. 56 out of 64 countries (OECD, 2010) and no. 58 out of 65 countries (OECD, 2013), respectively. Taking into account the problems above, we agree with Monereo et al. (2009) on the need to improve the educational system and in the suitability of doing so, starting precisely from the reflections issuing from the PISA results.

The contents of science are fundamental to achieving scientific literacy, as are aimed at answering the question how is known?, versus what is known? (Bartholomew, Osborne \& Ratcliffe, 2004).The statements regarding PISA show a shift in the approach to teaching that goes through all educational stages. The requirement of universities to prepare students in science competency is gaining more importance. In this sense, there is a growing body of research concerned with the identification and assessment of competencies, as they become an indicator of the quality of education provided (Brown \& Glasner, 2003; Cano Garcia, 2008; Vivas \& Hevia, 2009; Prades \& Espinar, 2010). The fact that the PISA assessments do not depend on the curriculum can help to establish innovative approaches to teaching. To investigate the development of science competency from PISA 2006 (OCDE, 2008) perspective in the university freshmen year could provide some guidance on the priorities over quality education.

All of the above highlights the relevance acquired by training based on competencies and the learning context of the new curricula. Therefore, the aim of this paper is to assess which science competency students possess when they enroll in the School of Biochemistry and Biology Science (first year in the courses of Biochemistry and Biotechnology) and which competency they possess when they complete the first year of the above courses mentioned.

It must be highlighted that teaching is a secondary duty for most scientific bodies at universities, since they generally develop teaching skills as a consequence of their teaching practice. Their limited training on science teaching methodologies and, in general, the little 
involvement of university science teachers in the research into science teaching is expressed by Dehaan (2005).

Given that the courses are becoming ever more specialized, research into which Chemistry content is more suitable for students of different age groups and courses, as well as which teaching methodologies prove to be the most efficient becomes ever more important (Gabel, 1999). Consequently, it was considered relevant to research into what is happening at the Argentinian higher education level, more specifically at the School of Biochemistry and Biology Science of the Universidad Nacional del Litoral.

As a consequence of the above, the following questions are put forward: What is the science competency of university students enrolling at the School of Biochemistry and Biological Sciences (courses of Biochemistry and Biotechnology)? What is the competency they have acquired by the time they finish their first year? What are their developments of the sub-competencies like? Does development of science competency depend on education in the first year of the courses mentioned?

The aim of this study is to assess the science competency of university students enrolling in the School of Biochemistry and Biological Sciences (first year of the courses of Biochemistry and Biotechnology at the National University of the Littoral, Argentina) and examine the effects of these courses on their competencies of Chemistry proficiency.

\section{Methodology of Research}

In this section, information about general background of research, characteristics of the sample, data collection and analysis, validity and reliability and procedures of the courses are provided.

\section{General Background of Research}

This descriptive study is based on the ex post facto type (non experimental). It focused on the analysis assessing the science competency as dependent variable of the instruction received in the first year courses of Biochemistry and Biotechnology without taking into account neither the procedures of the courses nor the teaching intervention. This research includes aspects of quantitative and qualitative methodologies (Cohen y Manion, 2002; Bisquerra Alzina, 2004).

Standard statistical techniques were used. Categorical variables were analyzed by ChiSquare Test and the Fisher's exact test, whenever appropriate (Agresti, 2002). All analyses were conducted by R (R Development Core Team, 2010).

\section{Subjects and Characteristics of the Sample}

The research started with a sample of 84 first-year undergraduate students and the makeup was as follows: 47 students of 1st year of Biochemistry (B) and 37 students of 1st year of Biotechnology (LB). Participating students were volunteers. The sample consisted of 84 students $77 \%$ of whom were female and $23 \%$ were male and the average age of the subjects was 18 years old. The students came from public $(58 \%)$ and private $(42 \%)$ secondary schools with medium socio-economic status. The selection was performed using stratified sampling, seeking homogeneity within each stratum and heterogeneity among strata. The number of students is considered adequate -greater than $10 \%$ of students enrolled, according to the recommendation by Colás Bravo \& Buendía Eisman (1998).

Subsequently, towards the end of that same year the research was continued with a sample of 50 of the same students: 27 of Biochemistry and 23 of Biotechnology. Such decrease in the number of subjects in the sample was due to voluntary or forced dropout from a course, 
Claudia Beatriz FALICOFF, Jose Manuel Domínguez CASTIÑEIRAS, Hector Santiago ODETTI. Science Competency of Argentinian University Students in the First Year of Biochemistry and Biotechnology Courses

PROBLEMS

OF EDUCATION

IN THE $21^{\text {st }}$ CENTURY

Volume 62,2014

either temporarily or permanently. During that year, the aforesaid students enrolled, among others, in the following subject matters related to chemistry knowledge: General Chemistry and Inorganic Chemistry. This makes both groups eligible to assess their degree of preparedness to face the daily challenges of modern society and thus obtain a quite approximate idea of the competencies that they have achieved during their first year in the University course. It must be clarified that during the first year, students attend the same courses (chemistry, biology, labs, etc.) in both, Biochemistry and Biotechnology.

\section{Information Collection Strategy}

This section describes the information collection strategy, to which purpose two questionnaires on science competency have been drafted and used.

Two different questionnaires were designed based on the definition of science competency in the PISA 2006 report, which may be characterized by four interrelated aspects (OECD 2002, 2004 and 2006): skills, knowledge, areas of application and attitudes; and some tests in the aforesaid report were selected. Subsequently, such tests have been adapted to the university level and other tests of our own design have also been used to draft the questionnaires. Three levels of description and interpretation -macroscopic, microscopic and symbolic (Johnstone, 1993)- of chemistry knowledge were assessed in different contexts, considered to be desirable from the viewpoint of academic knowledge.

During the study, the first questionnaire contained 17 questions and was divided into two topics: acid rain (10) and caries (7). It was drafted at the beginning of the year to determine the science competency of first-year students.

The second questionnaire consisted of 15 questions, distributed according to the same topics, 8 and 7 respectively. It was drafted at the end of the year, in order to explore the influence that teaching and learning may have had on the acquisition of such competencies.

These topics were selected given that the areas of application (Environment and Health) are closely connected to the courses of Biochemistry and Biotechnology where this study was conducted. Each question enables to assess one of the science skills, requiring the use of either knowledge of science or knowledge about science. Both topics assess (through different questions) more than one skill and more than one field of knowledge.

\section{Validity and Reliability}

The internal validity in the design of the questionnaire on science competency is established by taking the base model of the items designed and the study validated by PISA. Likewise, the internal rational method has been used which enables to determine the validity of a given instrument, checking whether it measures that which it has been designed for, that is to say, in this case, whether it measures the science sub-competencies: ISI, EPS and USE.

Cronbach's Alpha was chosen from among the most usual methods to measure the degree of reliability of the instruments. The values for $\alpha=0.72$ and $\alpha=0.75$ for the first and second questionnaires respectively indicate that the opinion results of the 84 students with respect to the 17 items analyzed and of the 50 students with respect to the 15 items considered correlate in a highly reliable and acceptable manner.

Therefore, in order to reach the final version of the instrument, a group of experts from our faculty were requested to read and consider the texts that are being assessed in each item and the corresponding answer keys. 
Claudia Beatriz FALICOFF, Jose Manuel Domínguez CASTIÑEIRAS, Hector Santiago ODETTI. Science Competency of Argentinian University Students in the First Year of Biochemistry and Biotechnology Courses

\section{Strategy for Information Analysis}

The categories «maximum score», «partial score» and «no score» divide the students' answers into three groups, according to the skills they show when answering the question asked. An answer qualified with the «maximum score» does not mean that the answer is absolutely correct in scientific terms, but that it does have the adequate level of understanding of the topic for a university student who is competent in science. Answers that are less elaborated, or not so correct, may obtain a «partial score». Answers that are incorrect, irrelevant or lack of answer will be marked with the category «no score» (Abraham, Gryzybowski, Renner \& Marek, 1992; Abraham, Williamson \& Westbrook, 1994).

The possible scoring for closed or multiple option questions varies from 0 to 2 points. Open questions, which may have different levels of correction, will have different scores ranging from 0 to 1 and 2 points. The appendices are an example of this.

Due to the numerical dispersion of the scores achieved, the results are grouped into performance levels. For the analysis of the Total performance of science competency (TPSC), the baseline or average considered was $50 \%$ of the total score, if all the answers obtained the maximum score. That is, out of a total of 17 questions, whose maximum score is 2 points each adding up to 34 points $(100 \%)$, the desirable score for the average level of performance was set at 17 points $(50 \%)$.

For the different competencies the baseline or average of $50 \%$ of the total score of each one of them was established, if all the answers had achieved the maximum score. That is, for:

-Identifying scientific issues (ISI), for example, out of a total of 3 questions, whose maximum score is 2 points each and in total add up to 6 points $(100 \%)$, the desirable score for the average level of performance was set at 3 points $(50 \%)$.

- Explaining scientific phenomena (EPS), for example, out of a total of 10 questions, whose maximum score is 2 points each and in total add up to 20 points $(100 \%)$, the desirable score for the average level of performance was set at 10 points $(50 \%)$.

- Using scientific evidence (USE), for example, out of a total of 4 questions, whose maximum score is 2 points each and in total add up to 8 points $(100 \%)$, the desirable score for the average level of performance was set at 4 points $(50 \%)$.

As has been stated above, it is considered that individuals possess several degrees of science competency and not that they may or not possess such competency in absolute terms. Therefore, in order to communicate the results by categories or in a continuous scale, an adaptation was made to the procedure of qualitative assessment and communication in percentages proposed by Biggs (2005, p. 236). According to this criterion, Table 1 presents the levels of science competency according to the range of scores obtained expressed in percentages.

Table 1. Scoring scales.

\begin{tabular}{ll}
\hline Category of qualification of competency & $\begin{array}{l}\text { Range } \\
\%\end{array}$ \\
\hline Reaches objectives at the maximum level & 100 to 70 \\
\hline Level of competency at average level & 70 to 50 \\
\hline Low performance level & $<50$ \\
\hline
\end{tabular}

For example, a student having achieved the following scores: $T P S C=13$ points; $I S I=5$; $E P S=4$ and $U S E=4$; corresponds respectively to $38 \%$ of the total of TPSC; $83 \%$ of $I S I ; 20 \%$ of EPS and $50 \%$ of USE. Consequently and according to Table 1, such student belongs in the 
Claudia Beatriz FALICOFF, Jose Manuel Domínguez CASTIÑEIRAS, Hector Santiago ODETTI. Science Competency of Argentinian University Students in the First Year of Biochemistry and Biotechnology Courses

PROBLEMS

OF EDUCATION

IN THE $21^{\text {st }}$ CENTURY Volume 62, 2014

following levels: low in TPSC; maximum for ISI; low in EPS and average for USE. Subsequently, the amount of students in each category or level was counted according to Table 1, and the relevant percentage of the total students was estimated for each sub-sample.

\section{Procedures of the Courses}

The procedures in the courses take place in traditional teaching, such as lectures, laboratory, workshops and tests.

It should be pointed out that, in the first year, rigid approaches still prevail in the curriculums of these courses.

\section{Results of Research}

Table 2 contains the performance results of the science competency for each instances assessed, expressed as the percentage of students who achieved the different levels of performance. The aforesaid table expresses the following taxonomic categories described above: TPSC, ISI, EPS and USE.

Table 2. Percentages of levels of science competency of first-year students in the courses of Biochemistry and Biotechnology.

\begin{tabular}{|c|c|c|c|c|c|c|c|}
\hline \multirow[b]{4}{*}{ Competency } & \multicolumn{7}{|c|}{ \% First-year students } \\
\hline & \multicolumn{3}{|l|}{ Biochemistry } & \multicolumn{4}{|c|}{ Biotechnology } \\
\hline & \multirow{2}{*}{ PRE-CLASS } & \multirow{2}{*}{$\begin{array}{l}\text { POST- } \\
\text { CLASS }\end{array}$} & \multirow{2}{*}{$\begin{array}{l}\text { Student } \\
\text { variation (\%) }\end{array}$} & \multirow{2}{*}{ PRE-CLASS } & \multirow{2}{*}{$\begin{array}{l}\text { POST- } \\
\text { CLASS }\end{array}$} & \multirow{2}{*}{$\begin{array}{l}\text { Student } \\
\text { varia- } \\
\text { tion (\%) }\end{array}$} & \\
\hline & & & & & & & Score \\
\hline TPSC & 2 & 8 & 6 & 0 & 0 & 0 & \multirow{4}{*}{$\begin{array}{l}\text { Maximum } \\
\text { level } \\
\text { (\% score } \\
\text { obtained } \\
100 \text { to } 70 \text { ) }\end{array}$} \\
\hline$|S|$ & 17 & 37 & 20 & 14 & 22 & 8 & \\
\hline EPS & 0 & 7 & 7 & 0 & 0 & 0 & \\
\hline USE & 32 & 4 & -28 & 30 & 9 & -21 & \\
\hline TPSC & 21 & 22 & 1 & 3 & 30 & 27 & \multirow{3}{*}{$\begin{array}{l}\text { Average } \\
\text { level (\% score } \\
\text { obtained } \\
70 \text { to } 50)\end{array}$} \\
\hline$|S|$ & 43 & 30 & -13 & 35 & 26 & -9 & \\
\hline EPS & 17 & 33 & 16 & 8 & 22 & 14 & \\
\hline USE & 38 & 26 & -12 & 38 & 39 & 1 & \\
\hline TPSC & 77 & 70 & -7 & 97 & 70 & -27 & \multirow{4}{*}{$\begin{array}{l}\text { Low level } \\
\text { (\% score } \\
\text { obtained } \\
<50)\end{array}$} \\
\hline$|S|$ & 40 & 33 & -7 & 51 & 52 & 1 & \\
\hline EPS & 83 & 60 & -23 & 92 & 78 & -14 & \\
\hline USE & 30 & 70 & 40 & 32 & 52 & 20 & \\
\hline
\end{tabular}

The results enabled to learn the extent of student performance in science competency, with regards to the length of enrollment and to each one of the university courses. In effect, it may be observed in Table 2:

Beginning the first year of education (pre-class):

- TPSC: total performance in science competency. In the first years of Biochemistry and 
Biotechnology, respectively, it was found that $77 \%$ and $97 \%$ of students are below the basic level set. This means that for this initial level most of the students in these courses, even though

having passed the exam to access University, lack a sound base of knowledge and skills from their school years.

-ISI: identifying scientific issues. Biochemistry and Biotechnology have, respectively, $40 \%$ and $51 \%$ of students below the basic level set.

-EPS: explaining phenomena scientifically, this is probably the sub-competency that is most worked with in the classroom as it is based on the application of scientific concepts. However, this is generally the competency with the lowest scores. The first years of Biochemistry and Biotechnology have, respectively, $83 \%$ and $92 \%$ of students below the basic level set. Both have $0 \%$ in the higher level, and Biochemistry (17\%) shows twice as much as Biotechnology $(8 \%)$ in the average level. First-year students of Biochemistry score better than those of Biotechnology to start with.

- USE: using scientific evidence, a competency focusing on evidence and argumentation, shows similar scores for both courses. First-year students of Biochemistry and Biotechnology are, respectively, $30 \%$ and $32 \%$ below the basic level. The highest percentages are in the average level (38\%). That is, this is the sub-competency with the best scores in this instance.

At the end of the first year, after one year of education (post-class):

- TPSC: Biochemistry course shows a slight increase in the maximum level of total performance of scientific competency (8\%). Most students of Biochemistry and Biotechnology are grouped into the average (22\%-30\%) and low (70\%-70\%) levels. Considering that these students have undergone one year of higher education, these findings are remarkably low.

-ISI: identifying scientific issues is the sub-competency that shows the greatest increase in the maximum level for both courses (37\%-22\%). The variation in Biochemistry is as follows: decrease by $7 \%$ and $13 \%$ in the low and average levels respectively, and increase by $20 \%$ in the high level. The variation in Biotechnology is: increase by $1 \%$ and $8 \%$ in the low and high levels, respectively, and decrease by $9 \%$ in the average level. Therefore, the improvement is more significant in Biochemistry as in Biotechnology the score for the low level remains practically the same $(52 \%)$.

- EPS: in both courses, explaining phenomena scientifically is the sub-competency revealing the greatest decrease in the low level: from $83 \%$ to $60 \%$ in Biochemistry and from $92 \%$ to $78 \%$ in Biotechnology. Even though for Biochemistry the percentages rise for both the average (33\%) as well as for the maximum (7\%) levels, in Biotechnology it only rises for the average level (22\%).

- USE: using scientific evidence is the sub-competency for which the percentage of students in the low level increases most; in Biochemistry from 30\% to $70 \%$ and in Biotechnology from $32 \%$ to $52 \%$. In Biochemistry in particular, the maximum and average levels decrease, almost doubling the low level. In Biotechnology the average level shows a slight increase and the maximum level decreases strongly ( $32 \%$ to $52 \%$ ).

For both courses, the categorical variables that are shown in Table 2, were analyzed.

In Biochemistry:

- TPSC: the level achieved by the students is independent from when this subcompetency was assessed (Chi-Square Test $\mathrm{p}=0.528$ ). The percentages of students in the low and average levels are virtually identical at both times. The values vary from $2,1 \%$ to $7,4 \%$ at maximum level, this variation is not statistically significant.

- ISI: the level achieved by the students is independent of when this sub-competency was assessed (Chi-Square Test $\mathrm{p}=0.149$ ). However, at the maximum level, there were $17 \%$ of students at the pre-class and $37 \%$ at the post-class.

- EPS: the level achieved by the students is independent of when this sub-competency was assessed (Chi-Square Test $\mathrm{p}=0.075$ ). Despite this, at the low level, it appears that at the preclass there were $83 \%$ of students and $60 \%$ at the post-class. 
Claudia Beatriz FALICOFF, Jose Manuel Domínguez CASTIÑEIRAS, Hector Santiago ODETTI. Science Competency of Argentinian University Students in the First Year of Biochemistry and Biotechnology Courses

PROBLEMS

OF EDUCATION

IN THE $21^{\text {st }}$ CENTURY Volume 62, 2014

- USE: the level achieved by the students is dependent on when this sub-competency was assessed (Chi-Square Test $\mathrm{p}=0.001$ ). It is necessary to highlight that, at the maximum level there were $32 \%$ of students at the pre-class and only the $4 \%$ at the post-class.

In Biotechnology:

- TPSC: the level achieved by the students is dependent of when this sub-competency was assessed (Fisher's exact Test $\mathrm{p}=0.04$ ). There was a significant decrease in the percentage of students in the lowest level at the end of the year, from $97 \%$ to $70 \%$ and this caused the increase in the average level.

- ISI: the level achieved by the students is independent of when this sub-competency was assessed (Chi-Square Test $\mathrm{p}=0.624$ ).

- EPS: the level achieved by the students is independent of when this sub-competency was assessed (Fisher's exact Test $\mathrm{p}=0.132$ ).

- USE: the level achieved by the students is independent of when this sub-competency was assessed (Chi-Square Test $\mathrm{p}=0.117$ ).

\section{Discussion}

It must be stated that the goals for the study were a) to find a trend of change in spite of individual variability, and b) track development - that could be done by taking common paths of students (pre, and post but also describing their process of learning in the course). Besides, it is difficult to assess competencies only through written tests, therefore it would be necessary to assess students' actions and their self-assessment processes (Brown \& Glasner, 2003).

It should be pointed out that the obtained results couldn't be corroborated with other researchers as no similar work was found.

The results achieved in this study have led to new questions that will be addressed in future research. It is particularly important to analyze in greater detail some of the elements that influence the development of each sub-competency, such as, for example, the use of models to explain scientific phenomena; the use of scientific evidence to draft an explanation; and which features of the experimental activities may foster student involvement to identify scientific issues. Moreover, the queries that have been performed so far have been in Chemistry classes and with the first-year students. In order to be able to discuss in further depth the influence of the education that is taught, it must conduct both longitudinal and transversal studies at different periods of higher education.

There is awareness that further research into the assessment and evolution of the students' science competency could provide a better understanding of students' difficulties and teachers' resources when developing and improving such competencies.

Performance could be improved if when designing, implementing and evaluating the curriculum more emphasis were given to science competency, with the following priorities:

- Interpreting scientific evidence and drafting and communicating conclusions.

- Insisting on qualitative scientific explanations, with emphasis on the application of the knowledge of scientific concepts in a given situation, describing or interpreting phenomena.

- Identifying problems that are susceptible of scientific research. Knowing the main characteristics of research. Recognizing key words in order to search for information.

The implications brought forward by this new approach to the work of teacher bodies in general and to teaching in particular evidence that the assessment must be consistent with the remainder of elements in designing education schemes, and as a consequence, competencybased assessments must be incorporated (Gijbels, Van de Watering \& Dochy, 2005). 


\section{Conclusions}

Considering that the students' initial science competency is different and that the learning processes are personal and possibly different for each individual, it cannot be expected that one single assessment perspective will be totally effective in the sense that they will all develop and express the aforesaid competencies in the same way. However, considering that learning is an enrichment of the individual's cognitive and emotional structure, it can be concluded, taking into account the results, that learning is a gradual process and not one of a linear change of ideas, and that the evolution of competency is connected to such process.

Coinciding with the above, in TPSC, both courses show low scores at the beginning of the study. Then the results improve very slightly with education.

In respect of the sub-competencies assessed, in ISI and EPS, Biochemistry students develop and improve such skills with education to a greater extent than does Biotechnology.

In the sub-competency USE, the students of both courses start off with similar baseline values and they do not improve with education, even less in Biochemistry.

The study practically started with two similar groups and ended in the same way. The development of science competency doesn't depend on education in the first year of the courses of Biochemistry and Biotechnology.

\section{Acknowledgements}

To the Projects:

-EDU2012-38022-C02-01. Ministry of Economy and Competitiveness, Spain.

- CAI+D 2009-12/B030. National University of the Littoral, Argentina.

Msc. Liliana E. Contini, National University of the Littoral, Argentina.

\section{References}

Abraham, M. R., Gryzybowski, E. B., Renner, J. W., \& Marek, A. E. (1992). Understanding and misunderstanding of eighth graders of five chemistry concepts found in textbooks. Journal of Research in Science Teaching, 29 (2), 105-120.

Abraham, M. R., Williamson, V. M., \& Westbrook, S. L. (1994). A cross-age study of the understanding of five concepts. Journal of Research in Science Teaching, 31 (2), 147-165.

Agresti, A. (2002). Categorical data analysis (Second Edition). New York: John Wiley \& Sons.

Bartholomew, H., Osborne, J., \& Ratcliffe, M. (2004). Teaching students "ideas-about-science": Five dimensions of effective practice. Science Education, 88 (5), 655-682.

Biggs, J. (2005). Calidad del aprendizaje universitario. Madrid: Narcea.

Bisquerra Alzina, R. (Ed.). (2004). Metodología de la investigación educativa. $1^{\circ}$ Ed. Madrid: La Muralla.

Brown, S., \& Glasner, A. (Ed.) (2003). Evaluar en la universidad. Problemas y nuevos enfoques. Madrid: Narcea.

Bybee, R. W. (1997). Achieving scientific literacy: from purposes to practices. Portsmouth NH: Heinemann.

Çalik, M., \& Coll, R. C. (2012). Investigating socioscientific issues via scientific habits of mind: Development and validation of the scientific habits of mind survey. International Journal of Science Education, 34 (12), 1909-1930.

Çalik, M., Turan, B., \& Coll, R. C. (2013). A cross-age study of elementary student teachers' scientific habits of mind concerning socioscientific issues. International Journal of Science and Mathematics Education. Published online: http://link.springer.com/article/10.1007/s10763-013-9458-0.

Cano García, M. E. (2008). La evaluación por competencias en la educación superior. Profesorado. Revista de currículum y formación del profesorado, 12 (3), 1-16. URL: http://www.ugr.es/local/ recfpro/rev123COL1.pdf [14-03-2012]. 
Claudia Beatriz FALICOFF, Jose Manuel Domínguez CASTIÑEIRAS, Hector Santiago ODETTI. Science Competency of Argentinian University Students in the First Year of Biochemistry and Biotechnology Courses

PROBLEMS

OF EDUCATION

IN THE $21^{\text {st }}$ CENTURY

Volume 62,2014

Cohen, L., Manion, L. (2002). Métodos de investigación educativa. Madrid: La Muralla.

Colás Bravo, M. P., \& Buendía Eisman, L. (1998). Investigación educativa. $3^{\text {a }}$ Ed. Sevilla: Alfar.

Dehaan, R. (2005). The impending revolution in undergraduate science education. Journal of Science Education and Technology, 14 (2), 253-269.

Gabel, D. (1999). Improving teaching and learning through Chemistry Education Research: A Look to the Future. Journal of Chemical Education, 76 (4), 548-554.

Gijbels, D., Van de Watering, G., \& Dochy, F. (2005) Integrating assessment tasks in a problem-based learning environment. Assessment and Evaluation in Higher Education, 30, 73-86.

Gilbert, J. (2006). On the nature of 'Context' in chemical education. International Journal of Science Education, 28 (9), 957-976.

Harlen, W. (2002). Evaluar la alfabetización científica en el programa de la OCDE para la evaluación internacional de estudiantes (PISA). Enseñanza de las Ciencias, 20 (2), 209-216.

Hodson, D. (2003). Time for action: Science education for an alternative future. International Journal of Science Education, 25 (6), 645-670.

Johnstone, A. H. (1993). The development of chemistry teaching. Journal of Chemical Education, 70, 701-705.

Monereo, C. (Coord.), Álvarez, I. M., Canal, M., Castelló, M., Cerrato, P., Corcelles, M., Duran, D., Gómez, I., Lemus, R., Núñez, M., Serrano, S., \& Vicente, L. (2009). PISA COMO EXCUSA. Repensar la evaluación para cambiar la enseñanza. Barcelona: Graó.

OCDE (2002). Muestra de reactivos empleados en la evaluación PISA 2000. Aptitudes Para Lectura, Matemáticas y Ciencias. México: Editorial Santillana. S. A.

OCDE (2004). Marcos teóricos de PISA 2003: la medida de los conocimientos y destrezas en matemáticas, lectura, ciencias y resolución de problemas. Madrid: MEC e INECSE.

OCDE (2006). PISA 2006: Marco de la evaluación. Conocimientos y habilidades en Ciencias, Matemáticas y Lectura. URL: http://browse.oecdbookshop.org/oecd/pdfs/browseit/9806034E. PDF [20- 02-2009].

OCDE (2008). Informe PISA 2006. Competencias cientificas para el mundo del mañana. Madrid: Santillana Educación, S. L.

OECD (2010). PISA 2009 Results: What Students Know and Can Do - Student Performance in Reading, Mathematics and Science (Volume I). URL: http://www.oecd.org/dataoecd/54/12/46643496.pdf [10-12-2010].

OECD (2013). PISA 2012 Results in Focus. URL: http://www.oecd.org/pisa/keyfindings/pisa-2012-results-overview.pdf [05-12-2013].

Osborne, J., \& Dillon, J. (2008). Science education in Europe: Critical reflections. A Report to the Nuffield Foundation. London: King's College.

Prades, A. \& Espinar, S. R. (2010). Laboratory Assessment in Chemistry: An Analysis of the Adequacy of the Assessment Process. Assessment \& Evaluation in Higher Education, 35(4), 449-461.

R Development Core Team (2010). R: A language and environment for statistical computing. Vienna, Austria: R Foundation for Statistical Computing. Retrieved 12/09/2010, from URL: http://www.R-project.org/.

Ültay, N., \& Çalik, M. (2012). A thematic review of studies into the effectiveness of context-based chemistry curricula. Journal of Science Education and Technology, 21 (6), 686-701.

Vivas, A. J., \& Hevia, D. M. A. (2009). Professionalization in Universities and European Convergence. Higher Education in Europe, 34 (3-4), 399-409.

Advised by Muammer Calik, Karadeniz Technical University, Turkey

Received: October 14, 2014

Accepted: November 17, 2014 
Claudia Beatriz FALICOFF, Jose Manuel Domínguez CASTIÑEIRAS, Hector Santiago ODETTI. Science Competency of Argentinian University Students in the First Year of Biochemistry and Biotechnology Courses

PROBLEMS

OF EDUCATION

IN THE $21^{\text {st }}$ CENTURY

Volume 62, 2014

3

\begin{tabular}{|ll|}
\hline Claudia Beatriz Falicoff & $\begin{array}{l}\text { PhD, Lecturer, National University of the Littoral, Faculty of Biochemistry and } \\
\text { Biological Sciences, Ciudad Universitaria Paraje EI Pozo, CC 242. (3000) } \\
\text { Santa Fe, Argentina. } \\
\text { E-mail: falicoff@fbcb.unl.edu.ar }\end{array}$ \\
\hline $\begin{array}{l}\text { Jose Manuel Domínguez } \\
\text { Castiñeiras }\end{array}$ & $\begin{array}{l}\text { PhD, Lecturer, University of Santiago de Compostela, Avda. Xoan XXIII, s/n. } \\
\text { 15704, Santiago de Compostela, Spain. } \\
\text { E-mail: josemanuel.dominguez@usc.es }\end{array}$ \\
\hline Hector Santiago Odetti & PhD, Lecturer, Faculty of Biochemistry and Biological Sciences, Ciudad Univer- \\
sitaria Paraje El Pozo, CC 242. (3000) Santa Fe, Argentina. \\
E-mail: hodetti@fbcb.unl.edu.ar
\end{tabular}

